\title{
ASPEK MANAJEMEN PADA STUDI KELAYAKAN BISNIS
}

Makalah ini Disusun untuk memenuhi Tugas pada Mata Kuliah Studi

Kelayakan Bisnis

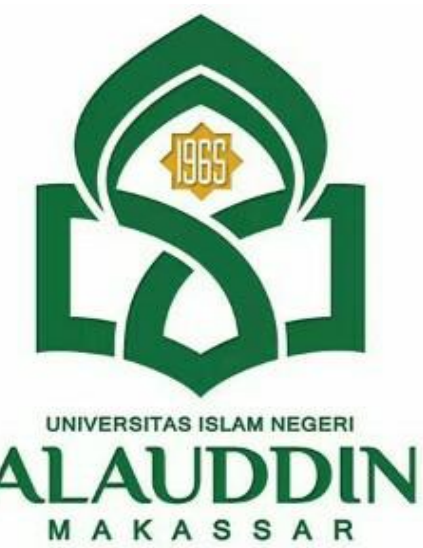

Oleh :

KELOMPOK 4

- $\quad$ GUSTI YUSMIANA $\quad 90500120109$

- FAHIRA ALIMIN $\quad 90500120125$

- IRAHMNI $\quad 90500120091$

- WINDA AULYA 90500120113

FAKULTAS EKONOMI DAN BISNIS ISLAM

UNIVERSITAS ISLAM NEGERI ALAUDDIN MAKASSAR

$2020 / 2021$ 


\section{KATA PENGANTAR}

Puji syukur kita panjatkan kepada Tuhan Yang Maha Esa karena atas rahmat dan karunia-Nya kita dapat menyelesaian makalah "ASPEK MANAJEMEN ". Dan kami berterima kasih kepada bapak Supriadi, S.E.I., M.E.I sebagai Dosen mata kuliah Studi Kelayakan Bisnis yang telah memberikan tugas kepada kami.

Kami sangat berharap makalah ini dapat berguna dalam rangka menambah wawasan serta pengetahuan kita sebagai penulis maupun pembaca. Kami menyadari bahwa dalam penulisan makalah ini masih terdapat banyak kekurangan dan jauh dari apa yang kami harapkan. Kami mohon maaf apabila terdapat kesalahan kata kata yang kurang berkenan dalam penulisan makalah ini. Oleh karena itu kami mengharapkan kritik dan saran yang membangun untuk menyempurnakan makalah ini untuk menjadi lebih baik lagi.

Wajo , 24 September 2021

Kelompok 4 


\section{DAFTAR ISI}

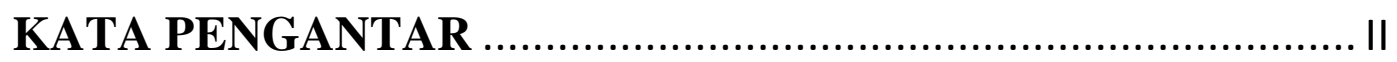

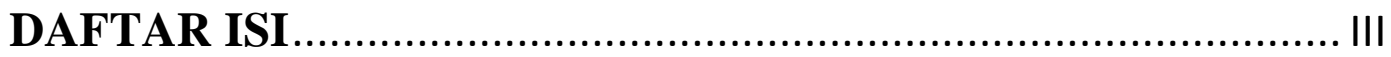

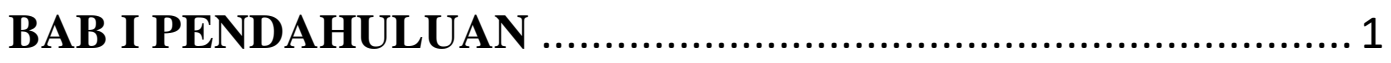

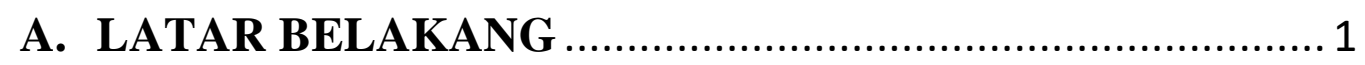

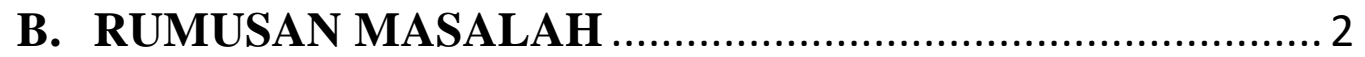

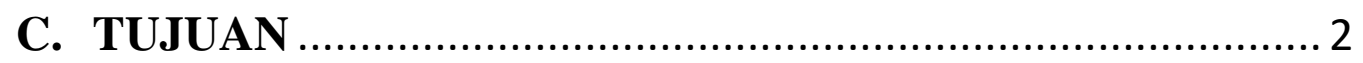

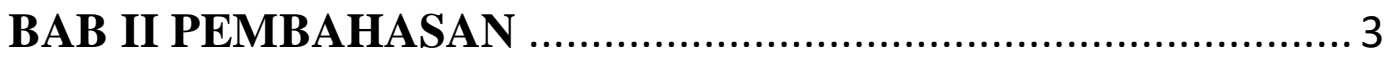

1. Aspek Manajemen ............................................................ 3

2. Mengakhiri Pembangunan Proyek ……............................ 8

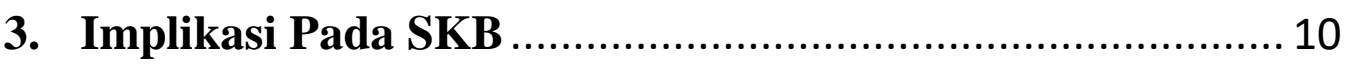

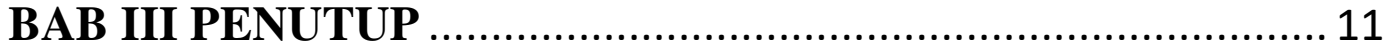

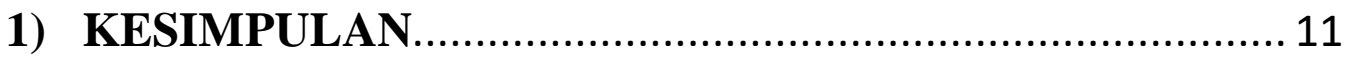

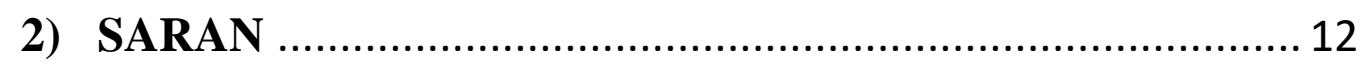

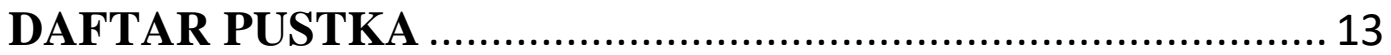




\section{BAB I}

\section{PENDAHULUAN}

\section{A. LATAR BELAKANG}

Secara umun manajemen merupakan suatu seni dalam ilmu dan pengorganisasian seperti menyusun perencanaan, membangun organisasi serta pengorganisasiannya, pergerakan, dan pengendalian ataupun pengawasan. Dapat pula dimaksud bahwa manajemen ialah sesuatu ilmu pengetahuan yang sistematis agar bisa memahami mengapa dan bagaimana manusia saling bekerja sama supaya bisa menciptakan suatu yang berguna untuk orang lain ataupun kalangan tertentu serta masyarakat luas. Secara etimologis, pengertian manajemen ialah seni untuk melaksanakan serta mengendalikan. Manajemen ini pula dilihat sebagai ilmu yang mengarahkan proses memperoleh tujuan dalam organisasi, sebagai usaha bersama dengan sebagian orang dalam organisasi tersebut. Sehingga, terdapat orang yang merumuskan serta melaksanakan tindakan manajemen yang disebut dengan manajer ${ }^{1}$.

Aspek manajemen serta organisasi ialah perihal yang tidak terpisahkan dari sebagian aspek kajian. Dimana keberhasilan suatu aktivitas bisnis yang sudah dinyatakan feasible untuk dikembangkan, sangat dipengaruhi oleh peranan manajemen dalam penyampaian tujuan. Aspek manajemen bertujuan guna mengetahui apakah aktivitas serta implementasi bisnis bisa direncanakan,

\footnotetext{
${ }^{1}$ Pendekatan manajemen strategic dalam rangka meningkatkan minat wirausaha masyarakat kelurahan rempo tangerang selatan
} 
dilaksanakan, sehingga rencana bisnis bisa dinyatakan layak ataupun sebaliknya tidak layak. Mengingat pentinya peranan aspek manajemen dalam memastikan keberhasilan suatu aktivitas/ bisnis yang dilakukan hingga perlu diadakan suatu analisis untuk kelayakan suatu usaha dengan melaksanakan perencanaan, pengorganisasian, penggerakan serta pengawasan.

\section{B. RUMUSAN MASALAH}

1. Bagaimana aspek aspek dalam manajemen ?

2. Bagaimana mengakhiri pembangunan proyek ?

3. Bagaiamana implikasi pada SKB ?

\section{TUJUAN}

1. Untuk mengetahui aspek aspek manajemen

2. Untuk mengetahui tentang mengakhiri pembangunan proyek

3. Untuk mengetahui tentang implikasi pada SKB 


\section{BAB II \\ PEMBAHASAN}

\section{Aspek Manajemen}

Aspek manajemen dan organisasi merupakan aspek yang lumayan penting untuk kelayakan suatu usaha, sebab meski suatu usaha sudah dinyatakan layak untuk dilaksanakan tanpa didukung dengan manajemen serta organisasi yang baik, bukan tidak bisa jadi akan mengalami kegagalan. Baik dalam menyangkut SDM ataupun menyangkut rencana perusahaan disusun sesuai dengan tujuan perusahaan dimana akan lebih mudah tercapai bila memenuhi kaidah kaidah tersebut ataupun tahapan dalam proses manajemen.

Adapun fungsi fungsi dari aspek manajemen antara lain:

\section{a. Perencanaan( Planning)}

Perencanaan merupakan proses memastikan arah yang bakal ditempuh serta aktivitas aktivitas yang dibutuhkan untuk menggapai tujuan yang sudah ditetapkan. Dalam proses ini ditentukan tentang apa yang harus dicoba, kapan serta bagaimana melaksanakannya dan dengan metode apa perihal tersebut dilakukan. Perencanaan ini ialah langkah dini saat sebelum melakukan fungsi- fungsi manajemen yang lain yaitu menetapkan pekerjaan yang harus di laksanakan oleh sekelompok orang guna meraih tujuan yang digariskan oleh lembaga/ organisasi. Adapun 4 macam pendekatan utama dalam pembuatan suatu perencanaan: ${ }^{2}$

\footnotetext{
${ }^{2}$ Dr. Kasmir, SE,M.M Studi Kelayakan Bisnis hal 168-169
} 
1. Pendekatan Atas- Bawah( Top- Down). Pimpinan puncak membagikan pengarahan serta petunjuk kepada pemimpin cabang ataupun sejenisnya untuk menyusun rencana yang pada tahapannya bakal ditinjau serta dikoreksi oleh pimpinan puncak saat sebelum disetujui untuk direalisasikan.

2. Pendekatan Bawah- Atas( Bottom- Up). Pemimpin puncak membagikan gambaran suasana serta keadaan yang dialami organisasi termasuk mengenai misi, tujuan, sasaran, dan sumber daya yang dipunyai.

3. Pendekatan Campuran. Pemimpin membagikan petunjuk perencanaan organisasi secara garis besar sedangkan perencanaan detailnya di serahkan kepada kreativitas unit perusahaan di bawahnya dengan senantiasa mematuhi ketentuan yang ada.

4. Pendekatan Kelompok. Dengan pendekatan ini, perencanaan terbuat oleh sekelompok tenaga pakar dalam perusahaan.

\section{b. Pengorganisasian( Orgamizing)}

Pengorganisasian merupakan proses mengelompokkan bermacam aktivitas ataupun pekerjaan dalam unit unit. Tujuannya yaitu agar terata dengan jelas antara tugas, wewenang, serta tanggung jawab dan jalinan kerja dengan sebaik mungkin dalam bidangnya masing masing. Hasil dari pengorganisasian ini adalah terbentuknya sturktur organisasi sesuai dengan rencana yang sudah disusun.

\section{Struktur Organisasi}


Dalam perihal ini menjelaskan pembagian kegiatan kerja, dan mencermati hubungan fungsi serta kegiatan tersebut hingga batasbatas tertentu. Terdapat 4 elemen dalam struktur, ialah:

a. Spesialisasi aktivitas, mengacu pada spesifikasi tugas- tugas perorangan dan kelompok kerja di segala organisasi( pembagian kerja) serta penyatuan tugas- tugas tersebut ke dalam unit kerja.

b. Standarisasi aktivitas, ialah prosedur yang digunakan organisasi untuk mengarah kelayakdugaan( predictability) aktivitasaktivitasnya.

c. Koordinasi aktivitas, merupakan prosedur dalam memadukan fungsi- fungsi sub- unit dalam organisasi.

d. Besar unit kerja, berhubungan dengan jumlah pegawai yang terletak dalam suatu kelompok kerja.

\section{Bentuk Organisasi}

a) Organisasi Garis. Bentuk organisasi ini ialah bentuk yang sangat simpel. Cirinya:

- Jumlah karyawan relatif sedikit.

- Organisasi relatif kecil.

- Karyawan saling mengenal secara akrab.

- Spesialisasi kerja masih relatif rendah. 
b) Organisasi Fungsional. cirinya yaitu bahwa tiap atasan memiliki wewenang untuk memberikan perintah kepada tiap bawahan yang $\operatorname{ada}^{3}$.

c) Organisasi Garis dan Staf. Di dalam organisasi yang begitu kompleks, pimpinan umumnya mendelegasikan wewenang kepada para staf sesuai dengan bidang masing- masing.

d) Organisasi Gabungan. Mengenai kebaikan dan kelemahan bentuk organisasi kombinasi ataupun gabungan ini hendak mengikuti kebaikan serta kelemahan organisasi- organisasi yang dibawa dalam rangka penggabungan tersebut.

e) Organisasi Matriks. Dalam organisasi matriks, seseorang bawahan memiliki lebih dari satu, misalnya 2 orang atasan, sehingga mereka di bawah 2 jalur wewenang ataupun dengan kata lain memiliki 2 rantai perintah, yang satu secara vertikal( bertabiat fungsional). ${ }^{4}$

\section{c. Pelaksanakan/ Penggerakan( Actuating)}

Melasanakan adalah proses untuk melaksanakan aktivitas ataupun pekerjaan dalam organisasi. Dalam melaksanakan organisasi para pemimpin ataupun manajer harus menggerakan bawahannya untuk menegrjakan pekerjaan yang sudah ditentukan dengan metode

${ }^{3}$ Dr. Kasmir, SE,M.M Studi Kelayakan Bisnis hal 168-169

${ }^{4}$ Dr. Kasmir, SE,M.M Studi Kelayakan Bisnis hal 168-169 
memimpin, memeberi perintah, berikan petunjuk, serta memberi motivasi. $^{5}$

\section{Fungsi Penggerakan}

Fungsi penggerakan di dalam manajemen yang pokok yaitu:

1. Mempengaruhi seseorang( orang- orang) agar bersedia jadi pengikut.

2. Melaksanakan daya tolak pada seseorang( orang- orang).

3. Membuat seseorang ataupun orang- orang suka mengerjakan tugas dengan lebih baik.

4. Memperoleh, memelihara dan memupuk kesetiaan pada pimpinan, tugas serta organisasi tempat mereka bekerja.

5. Menanamkan, memelihara serta memupuk rasa tanggung jawab seseorang atau orang- orang terhadap Tuhannya, negeri, serta masyarakat. ${ }^{6}$

\section{d. Pengawasan/ Pengendalian( Controling)}

Pengawasan merupakan proses untuk mengukur serta menilai penerapan tugas apakah sudah sesuai dengan rencana. Bila dalam proses tersebut terjadi penyimpangan, hingga akan segera dikendlikan sesuai

\footnotetext{
${ }^{5}$ Fungsi manajemen dalam pengadaan infrastruktur pertanian masyarakat di desa watatu kecamatan banawa selatan kabupaten donggala

${ }^{6}$ Fungsi manajemen dalam pengadaan infrastruktur pertanian masyarakat di desa watatu kecamatan banawa selatan kabupaten donggala
} 
dengan rencana yang disusun. Dengan terdapatnya pengendalian ini diharapkan tujuan dicapai sesuai dengan sasaran yang sudah ditetapkan. ${ }^{7}$

\section{Fungsi pokok pengendalian yaitu:}

a. Menghindari tejadinya penyimpangan- penyimpangan atau kesalahan dengan melaksanakan pengendalian secara rutin

b. Memperbaiki bermacam penyimpangan yang terjadi.

c. Mendinamisasikan organisasi.

d. Mempertebal rasa tanggung jawab.

\section{Jenis Pengendalian}

a. Tata cara Pengendalian Pendahuluan: membutuhkan bermacam standar mutu serta kuantitas yang layak dari berbagai masukan( input).

b. Tata cara Pengendalian Bertepatan( Concurrent Controls): membutuhkan standar sikap, aktivitas serta penerapan dari aktivitas secara layak.

c. Tata cara Pengendalian Umpan Balik( Feedback Controls): membutuhkan standar kuantitas serta mutu yang layak dari keluaran( output). Informasi itu harus mencerminkan bermacam ciri dari keluaran( output).( Dr. Nathanael Sitanggang, 2019) ${ }^{8}$

\section{Mengakhiri Pembangunan Proyek}

Langkah- langkah pokok berikut proses mengakhiri proyek bisnis:

${ }^{7}$ Dr. sugiyanto, SE, MM, CMA, CFRM, CT, CHt

${ }^{8}$ Dr. Nathanael Sitanggang, 2019 
1. Menetapkan organisator terminasi proyek.

2. Mengadakan pertemuan untuk mempersiapkan proses terminasi.

3. Mempersiapkan laporan dari masing- masing personil terminasi proyek.

4. Mengakhiri seluruh dokumen finansial.

5. Akhiri semua perintah kerja, kontrak, persetujuan, serta outstanding supplier.

6. Lengkapi seluruh dokumen dengan seluruh pihak yang terpaut, kemudian setujui.

7. Tutup seluruh bagian proyek serta mengembalikan seluruh peralatan proyek.

8. Jalani pos audit atas selesainya proyek.

9. Membuat statment persetujuan dari klien kalau proyek selesai dikerjakan.

10. Tutup seluruh bagian fisik proyek dan lakukan pemutusan jalinan kerja untuk staf proyek yang masih tersisa. ${ }^{9}$

${ }^{9}$ Karebet Gunawan, S. M ( 2018 ) 


\section{Implikasi Pada SKB ${ }^{10}$}

Hasil studi aspek manajemen sebaiknya membagikan informasi dalam 2 aktivitas pokok, ialah manajemen dalam pembangunan proyek bisnis serta manajemen dalam implementasi bisnis teratur dalam perihal:

1. Perencanaan. Sebaiknya SKB bisa menilai perencanaan dari sisi pendekatan yang digunakan, dari sisi jangka waktu serta dari sisi tingkatan manajemen.

2. Pengorganisasian. Sebaiknya SKB bisa mengkaji apakah langkahlangkah pengorganisasian di dalam 2 aktivitas pokok di atas dapat direncanakan serta diperkirakan hendak berjalan dengan baik.

3. Penggerakan. Sebaiknya SKB bisa mengkaji fungsi manajemen yang lain, ialah penggerakan( actuating), apakah layak ataupun tidak layak.

4. Pengendalian. Sebaiknya SKB sanggup mengkaji aspek pengendalian untuk kedua kegiatan pokok ini, sehingga bisa diambil keputusan layak ataupun tidak seperti atas aspek ini.

5. Mengakhiri pembangunan proyek. Sebaiknya SKB sanggup mengkaji supaya teknis implementasi atas penyelesaian proyek, saat sebelum dilanjutkan pada implementasi bisnisnya, bisa direncanakan dengan baik.

${ }^{10}$ Prof,. Dr. J. Winrdi, S. ( 2019) manajemen perilaku 


\section{BAB III}

\section{PENUTUP}

\section{1) KESIMPULAN}

Aspek Manajemen merupakan bagian yang tidak terpisahkan dari beberapa aspek kajian dalam suatu laporan studi kelayakan bisnis. Keberhasilan suatu proyek ataupun aktivitas yang sudah dinyatakan feasible untuk dikembangkan, sangat dipengaruhi oleh peranan manajemen dalam pencapaian tujuan proyek ataupun aktivitas. Aspek manajemen dalam studi kelayakan bisnis menyangkut fungsi- fungsi manajemen secara umum/ makro. Adapun Aspek- aspek manajemen antara lain:

1. Perencanaan( Planning) merupakan proses memastikan arah yang akan ditempuh serta aktivitas aktivitas yang dibutuhkan untuk meraih tujuan yang sudah ditetapkan,

2. Pengorganisasian, merupakan proses mengelompokkan bermacam aktivitas ataupun pekerjaan dalam unit unit. Tujuannya yakni agar terta dengan jelas antara tugas, wewenang, dan tanggung jawab dan ikatan kerja dengan sebaik mungkin dalam bidangnya masing masing

3. Pelaksaan ataupun penggerakan merupakan proses melaksanakan aktivitas atau pekerjaan dalam organisasi

4. Pengawasan/ Pengendalian( Controling),

Pengawasan merupakan proses untuk mengukur serta menilai penerapan tugas apakah sudah sesuai dengan rencana. Apabila dalam proses tersebut 
terjadi penyimpangan, maka akan segera dikendlikan sesuai dengan rencana yang disusun

\section{2) SARAN}

Kami sangat berharap makalah ini dapat berguna dalam rangka menambah wawasan serta pengetahuan kita sebagai penulis maupun pembaca, kami mengharapkan kritik dan saran yang membangun untuk menyempurnakan makalah ini untuk menjadi lebih baik lagi 


\section{DAFTAR PUSTKA}

Dr. Kasmir, S. M. (2017). Studi Kelayakan Bisnis . Jakarta: KENCANA.

Dr. Nathanael Sitanggang, S. M. (2019). Pengantar Konsep Manajemen Proyek untuk Teknik. Medan: Yayasan Kita Menulis .

Glendoh, S. H. (2000). Fungsi Pengawasan dalam Penyelenggaraan Manajemen Korporasi. Jurnal Manajemen dan Kewirausahaan, 2(1), 43-56.

Karebet Gunawan, S. M. (2018). Peran Studi Kelayakn Bisnis Dalam Peningkatan UMKM. Jurnal Bisnis, 6(2), 101 - 115.

Krisnaldy, A. S. (2020). PENDEKATAN MANAJEMEN STRATEGIK DALAM RANGKA MENINGKATKAN. Jurnal LOKABMAS Kreatif, 1(2), 16 - 23.

Prof. Dr. J. Winardi, S. (2019). Manajemen Perilaku Organisasi. Jakarta : Kencana.

Talibo, I. W. (2013). Fungsi Manajemen Dalam Perencanaan Pembelajaran. JURNAL ILMIAH IQRA', 7(1), 85 - 119. 